\title{
O enunciado à primeira vista: as (im)possibilidades de uma leitura da superfície dos discursos
}

\author{
The statement at first sight: the (im) possibilities of reading the surface of the \\ discourses
}

\author{
Vanice Maria Oliveira SARGENTINI \\ Universidade Federal de São Carlos (UFSCar) \\ Universidade Federal da Paraíca(UFPB) \\ http://orcid.org/0000-0002-7760-3075 \\ Joice Camila CORSI \\ Universidade Federal de São Carlos (UFSCar) \\ http://orcid.org/0000-0002-7194-6229
}

\begin{abstract}
RESUMO: Este artigo pretende expor, de forma didático-analítica, a produtividade de conceitos elaborados em "A Arqueologia do Saber" que se tornam centrais para os estudos do discurso. Com o método arqueológico, problematizamos como o conceito de enunciado fundamenta uma análise em que supostamente um mesmo enunciado pode ser compreendido diferentemente, ao ser produzido nos limites da raridade, do acúmulo e da exterioridade. Inscrito em um amplo arquivo dos discursos políticos pronunciados por presidentes a respeito dos migrantes e sobre a política migratória, o corpus compõe-se de enunciações da ex-presidenta Dilma Rousseff (2014-2016) e do presidente Jair Bolsonaro (2019-), em seus discursos por ocasião de suas participações nas sessões da Assembleia Geral das Nações Unidas (ONU). Pretendemos com a análise apontar que o conceito de enunciado no plano do discurso articulase à análise linguística, mas neste entrecruzamento legitima a produção de alguns sentidos e não de outros.
\end{abstract}

PALAVRAS-CHAVE: Arqueologia do Saber. Enunciado. Política migratória. Análise discursiva.

ABSTRACT: This article aims to expose, in a didactic-analytical way, the productivity of concepts elaborated in The Archaeology of knowledge that become central to discourse studies. With the archaeological method, we problematize how the concept of statement establishes an analysis in which supposedly the same statement can be understood differently, when it is produced within the limits of rarity, accumulation and externality. Included in a broad archive of political speeches made by presidents about migrants and about immigration policy, the corpus is composed of statements by ex-president Dilma Rousseff (2014-2016) and president Jair Bolsonaro (2019-), in their speeches on the occasion of their participation in the United Nations General Assembly (UN). With this analysis, we intend to point out that the concept of utterance in the discourse plane is linked to linguistic analysis, but in this intersection it legitimizes the production of some meanings and not others.

KEYWORDS: The Archaeology of knowledge. Statement. Migration policy. Discursive analysis 


\title{
Introdução: Arqueologia, 50 anos, contribuições para os estudos do discurso
}

\author{
Trata-se de revelar as práticas discursivas em \\ sua complexidade e em sua densidade; mostrar \\ que falar é fazer alguma coisa; mostrar que \\ somar um enunciado a uma série preexistente de \\ enunciados é fazer um gesto complicado e \\ custoso que implica condições e que comporta \\ regras. \\ Michel Foucault
}

"Não me pergunte quem sou e não me diga para permanecer o mesmo: é uma moral de estado civil; ela rege nossos papéis. Que ela nos deixe livres quando se trata de escrever" (Foucault, 2004, p 20). A frase irônica de Foucault expõe o quanto ele não pretendia fazer uma escola ou ser reconhecido por etiquetas. Revel (2010, p. 13) indica a complexidade do seu pensamento e as formas como era ambiguamente visto: às vezes uma figura tutelar de 1968, tornando-o um pensador singular no pós-guerra, pósmoderno, desconstrutivista; outras vezes um estruturalista, antimarxista, liberal e positivista. De fato, as etiquetas não lhe caem bem. De nossa parte, trata-se de fazer ressoar o pensamento de Foucault na análise dos enunciados. Pensar com ele sobre os enunciados que emergem, produzindo os acontecimentos. Será neste entrecruzamento dos discursos, da análise dos enunciados, da presença da função enunciativa e da construção histórica dos sujeitos que iremos expor a produtividade do livro A arqueologia do Saber nos estudos discursivos.

Neste artigo, objetivamos, de modo geral, expor a nucleação de conceitos provenientes de "A Arqueologia do Saber", livro que veio a expor os cortes epistemológicos, os deslocamentos científicos e o pensamento inovador de Michel Foucault, e de modo específico como o conceito de enunciado é central para os estudos do discurso, analisando como supostamente um mesmo enunciado pode ser compreendido diferentemente, ao ser produzido no interior de distintos construtos históricos, de um dado domínio associado, definido nos limites da raridade, do acúmulo e da exterioridade.

Inscrito em um amplo arquivo dos discursos políticos pronunciados por presidentes ou candidatos à presidência a respeito dos migrantes e sobre a política migratória, nosso corpus recortará enunciações da ex-presidenta Dilma Rousseff (20142016) e do presidente Jair Bolsonaro (2019 - ), em seus discursos diversos e em especial 
no pronunciamento de abertura nas sessões da Assembleia Geral das Nações Unidas ONU (no decorrer de seus mandatos), no que se refere à temática das migrações e da acolhida aos refugiados e estrangeiros no Brasil. Pretendemos com essa análise, em um exercício didático-analítico, apontar que o conceito de enunciado no plano do discurso articula-se à análise linguística mas não se reduz a ela. Em tempos em que a literalidade do dizer pode tanto gerar processos jurídicos como cair no esquecimento, é preciso mostrar que o objeto da descrição arqueológica não é "o objeto atômico - com seu efeito de sentido, sua origem, seus limites e sua individualidade - mas sim o campo de exercício da função enunciativa e as condições segundo as quais ela faz aparecer unidades diversas (que pode ser, mas não necessariamente, de ordem gramatical ou lógica)" (Foucault, 2004, p. 121)

\section{Conceitos e método}

A Arqueologia do saber é uma obra marcada por um desejo explícito de ruptura com a concepção da continuidade histórica, fato que faz surgir o acontecimento, inscrevendo-o em uma possibilidade de leitura fora dos quadros cronológicos, das racionalidades e das teleologias. É uma proposta metodológica de descrição e análise dos acontecimentos discursivos, que se referem não só a rupturas que instauram regularidades (aparecimento de novas práticas), mas também à análise da formação dessas novas práticas discursivas e seu caráter transformador. O acontecimento, portanto, pode conter simultaneamente a novidade e a regularidade apreensíveis no enunciado, como uma materialidade que expõe suas condições de existência.

Nesta perspectiva de análise arqueológica afastam-se então as noções fundamentais de consciência e de continuidade, bem como as de signo e de estrutura. São os conceitos de acontecimento, de série, de regularidade, de casualidade, de descontinuidade, de dependência, de transformação que regem a metodologia de análise (FOUCAULT, 1996, p. 56). Trata-se, portanto, de uma análise que se recusa a partir de universais. Ela pauta-se nas práticas discursivas para poder compreender a formação e transformação dos enunciados, para flagrar as rupturas que afetam o regime geral de uma ou de várias formações discursivas. É um modo de análise que busca nos enunciados efetivamente enunciados (sejam verbais ou imagéticos) as razões para sua emergência na dispersão dos acontecimentos. 
Os enunciados, conforme definidos em "A arqueologia do Saber", caracterizamse por terem uma função enunciativa (uma posição ocupada pelo sujeito), uma materialidade (com sua possibilidade de transformação e reutilização), uma referência (que não é um fato, um estado de coisas ou objeto, mas sim um princípio de diferenciação) e um campo associado (que não é o contexto da formulação, mas um domínio de coexistência) (FOUCAULT, 2004, p. 130). A descrição do enunciado deve considerá-lo como um elemento em condição de coexistência com outros enunciados, além disso, trata-se de compreender a existência de um enunciado no interior de diferentes funções enunciativas. Esse tipo de descrição leva o autor a afirmar que o enunciado embora não seja imediatamente visível (como seria se observado como uma estrutura gramatical ou lógica), também não é oculto (uma vez que se realiza efetivamente por meio de performances verbais): “é necessária uma certa conversão do olhar e da atitude para poder reconhecê-lo e considerá-lo em si mesmo" (FOUCAULT, 2004, p. 126).

Há várias razões para isso: o enunciado é pouco visível (i) porque ele não é uma unidade existente ao lado das frases ou proposições, ele está dentro de unidades desse gênero; (ii) porque a "estrutura significante da linguagem remete sempre a outra coisa" (FOUCAULT, 2004, p.126), então é preciso suspender a soberania do significado e do significante para fazer emergir no enunciado o domínio de objetos, os sujeitos possíveis, as formulações e reutilizações.

Se de fato o discurso fosse uma realidade facilmente observável, dedutível, um retrato do óbvio, como poderíamos justificar as possíveis e diferentes leituras de um mesmo enunciado? Como enunciados proferidos a respeito do mesmo assunto/tema, por sujeitos que usufruem das mesmas condições e lugares de fala, em rituais idênticos podem referir-se a realidades intocáveis e incompatíveis? Como enunciados praticamente semelhantes em sua forma, constituição sintática, em suas condições de produção e dispersão, revelam-se extremamente distintos em seu conteúdo?

Com fim didático-analítico, mobilizaremos a noção de formação discursiva (FOUCAULT, 2004) capaz de nos mostrar que enunciados semelhantes em sua construção linguística podem produzir sentidos díspares no plano discursivo. Essa dinâmica extrapola a materialidade verbal, a ideia de um sujeito autônomo e dono de seu dizer, e evidencia a presença de atravessamentos na constituição dos enunciados. Para alcançarmos tal objetivo, analisaremos os discursos da ex-presidenta, Dilma 
Rousseff durante sua passagem pela $70^{\circ}$ sessão da Assembleia Geral das Nações Unidas, no que se refere à temática das migrações, sobretudo na questão da acolhida aos refugiados e estrangeiros no Brasil, no decorrer de seu segundo mandato. Nossa proposta é analisar como as diferentes leituras de um mesmo enunciado podem ser mais assertivas se pudermos compreender que os enunciados e sujeitos são históricos, respondem às leis de raridade, exterioridade e acúmulo. Posteriormente, faremos o cotejamento com enunciados produzidos por Jair Bolsonaro na $74^{\mathrm{a}}$ Assembleia da ONU e em comentários sobre o mesmo tema postados por ele em redes sociais. Neste cotejamento vemos, em especial, que os enunciados guardam uma relação singular com a posição enunciativa daquele que o enuncia: "as mesmas palavras são utilizadas, basicamente os mesmos nomes, em suma, a mesma frase, mas não forçosamente o mesmo enunciado" (FOUCAULT, 2004, p.101).

\section{As práticas discursivas: análise de enunciados sobre movimentos migratórios}

A história das migrações, tal qual propõe uma historiografia tradicional, é milenar. Os nômades se deslocavam por inúmeros territórios. Exploravam a terra e seus recursos, que, uma vez esgotados, obrigavam um novo deslocamento. Precisavam encontrar uma região que oferecesse condições necessárias para sua sobrevivência. Mas, uma vez sedentários, esses grupos começaram a desenvolver a noção de propriedade, o que culminou na ideia de pertencimento. A partir daí a estigmatização do nomadismo e da imigração se disseminou. Migrar deixou de ser uma condição natural de toda a humanidade, e passou a ser apenas de algumas minorias, e as razões para a migração na atualidade se diferem daquelas dos povos primitivos. O tema das migrações está na ordem do dia. A forte "onda de migração" que tomou o mundo nos últimos anos evidenciou a problemática vivenciada por milhares de pessoas que precisaram, por inúmeros motivos, deixar sua terra natal e buscar acolhida em terras outras. Estados ditatoriais, guerras civis, perseguições políticas ou religiosas, violação dos direitos humanos e até catástrofes naturais são alguns dos fatores que configuram os "novos fluxos migratórios” (CAVALCANTI e col. (2019).

A questão migratória passou então a entrar na pauta das políticas governamentais. Os governos expõem suas posições políticas a esse respeito em distintas ocasiões: em pronunciamentos em Assembleias como na ONU, em entrevistas, 
em colunas de jornal, em expressão de posicionamento no Twitter. Para nossas análises recortamos alguns enunciados extraídos de declarações feitas por Dilma Rousseff e Jair Bolsonaro a respeito de suas políticas de acolhimento de migrantes no Brasil.

O par de enunciados desencadeadores de nossa análise é o seguinte:

Somos um país continental e todos os refugiados que quiserem vir trabalhar, viver em paz, ajudar a construir o país, criar seus filhos, viver com dignidade, nós estamos de braços abertos". [...]Temos nossas dificuldades, mas isso não significa que no nosso país não caibam sempre mais pessoas (ROUSSEFF, 2015 a)

Como os senhores podem ver, o Brasil é um país aberto ao mundo, em busca de parcerias com todos os que tenham interesse de trabalhar pela prosperidade, pela paz e pela liberdade (BOLSONARO, 2019)

\subsection{Enunciados em análise: Dilma Rousseff:}

Para iniciar as análises, coletamos algumas declarações da ex-presidente, destacadas pelo portal G1, no dia 26 de setembro de 2015, já na cidade sede da assembleia da ONU em Nova York (enunciado 1); o excerto do pronunciamento oficial da presidente Dilma Rousseff, na $70^{\circ}$ sessão da Assembleia Geral das Nações Unidas, em 28 de setembro de 2015 (enunciado 2) e um artigo: "Os refugiados e a esperança" de autoria da então presidenta, Dilma Rousseff, publicado pelo jornal Folha de S. Paulo, em 10 de setembro de 2015 (enunciado 3), antes mesmo de sua presença na assembleia da ONU.

\section{Enunciado 1.}

Somos um país continental e todos os refugiados que quiserem vir trabalhar, viver em paz, ajudar a construir o país, criar seus filhos, viver com dignidade, nós estamos de braços abertos.

[...]Temos nossas dificuldades, mas isso não significa que no nosso país não caibam sempre mais pessoas"(ROUSSEFF, 2015 a).

\section{Enunciado 2.}

Temas como os desafios urbanos, a questão de gênero, das mulheres e das meninas, as questões de raça, ganharam prioridade.

Não conseguiu o mesmo êxito ao tratar da segurança coletiva, questão que esteve na origem da Organização e no centro de suas preocupações. A multiplicação de conflitos regionais - alguns com alto potencial destrutivo -, assim como a expansão do terrorismo que mata homens, mulheres e crianças, que destrói patrimônio da humanidade, que expulsa de suas comunidades seculares milhões de pessoas, mostram que a ONU está diante de um grande desafio. Não se pode ter complacência com tais atos de barbárie, como aqueles perpetrados pelo chamado Estado Islâmico e por outros grupos associados. Esse quadro explica, em boa medida, a crise dos refugiados pela 
qual passa atualmente a humanidade. Grande parte dos homens, mulheres e crianças que se aventuram nas águas do Mediterrâneo e erram penosamente nas estradas da Europa provêm do Oriente Médio e Norte da África, onde países tiveram seus Estados nacionais desestruturados por ações militares ao arrepio do Direito Internacional, abrindo espaço para a proliferação do terrorismo.

A profunda indignação provocada pela foto de um menino sírio morto nas praias da Turquia e pela notícia sobre as 71 pessoas asfixiadas em um caminhão na Áustria deve se transformar em ações inequívocas de solidariedade prática. Em um mundo onde circulam, livremente, mercadorias, capitais, informações e ideias, é absurdo impedir o livre trânsito de pessoas.

O Brasil é um país de acolhimento, um país formado por refugiados. Recebemos sírios, haitianos, homens e mulheres de todo o mundo, assim como abrigamos, há mais de um século, milhões de europeus, árabes e asiáticos. Estamos abertos, de braços abertos para receber refugiados. Somos um país multiétnico, que convive com as diferenças e sabe a importância delas para nos tornar mais fortes, mais ricos, mais diversos, tanto cultural, quanto social e economicamente (ROUSSEFF, 2015, b)

\section{Enunciado 3.}

Mesmo neste momento de superação de dificuldades, o Brasil tem os braços abertos para acolher refugiados que queiram viver e trabalhar aqui. A crise dos refugiados do Oriente Médio e do norte da África, que assumiu contornos dramáticos nos últimos dias, arrasta-se há mais de quatro anos, especialmente a partir do início da guerra civil na Síria e da intervenção militar na Líbia.

(...)

Quando grandes crises se abateram sobre a Europa e sobre o Oriente, as portas do Brasil estiveram abertas para todos. Temos consciência da importância dessas contribuições para nossa formação histórica e cultural. Nós nos orgulhamos de ser um povo formado pela diversidade. É por isso que a tolerância e o respeito pelas diferenças são marcas da nossa identidade. Com esse espírito, recebemos atualmente mais de 28 mil cidadãos haitianos, o que continuaremos a fazer de forma solidária e legal. Ao mesmo tempo, combatemos os grupos criminosos -os chamados "coiotes"- que, na América Latina, no Oriente e na Europa, traficam pessoas, aproveitando-se do desespero de milhares de famílias que fogem da guerra e da pobreza em busca de um futuro de esperança.

O Brasil, mesmo neste momento de superação de dificuldades, tem os braços abertos para acolher refugiados. Reitero a disposição do governo brasileiro de receber aqueles que, expulsos de suas pátrias, para o Brasil queiram vir, viver, trabalhar e contribuir para a prosperidade e para a paz. Queremos oferecer-lhes essa esperança (ROUSSEFF, 2015, c)

Em uma análise do enunciado linguístico, encontramos no enunciado 1 duas possíveis interpretações, quer se leia o enunciado "Somos um país continental e todos os refugiados que quiserem vir trabalhar, viver em paz, ajudar a construir o país, criar seus filhos, viver com dignidade, nós estamos de braços abertos", considerando esse 
'que' como introdutor de uma oração restritiva ou de uma explicativa ${ }^{1}$. A primeira das análises sugere uma hospitalidade condicional por parte da ex-presidenta, enquanto a segunda leitura demonstra uma hospitalidade genuína, incondicional, evidenciada não apenas por seus pronunciamentos, mas também por toda uma série de políticas públicas criadas no decorrer de seu governo.

A presença no enunciado de um caráter condicional pode ser justificada: afirmase "Somos um país continental" e na sequência é inserida a conjunção com valor restritivo e condicional "que" (todos os refugiados que), sendo a próxima afirmação aquela que expressa as condições para que isso se concretize (quiserem vir trabalhar, viver em paz, ajudar a construir o país, criar seus filhos, viver com dignidade...). A declaração de Dilma pode ser parafraseada das seguintes maneiras:

Somos um país continental e todos os refugiados que quiserem vir trabalhar, viver em paz, ajudar a construir o país, criar seus filhos, viver com dignidade, nós estamos de braços abertos (Dilma Rousseff)

\section{Paráfrases:}

O Brasil é um país continental e estamos de braços abertos aos refugiados desde que venham para trabalhar, viver em paz, ajudar a construir o país, criar seus filhos e viver com dignidade.

Aos refugiados que quiserem vir para trabalhar, viver em paz, ajudar a construir o país, criar seus filhos e viver com dignidade, estaremos de braços abertos. O Brasil é um país continental.

Os trechos "trabalhar, viver em paz, ajudar a construir o país, criar seus filhos, viver com dignidade" seriam nesta leitura as condições impostas para uma boa acolhida, o que pressupõe uma conduta contrária a "braços abertos" no caso de os refugiados não atenderem a tais condições. O que também pressupõe que alguns refugiados poderiam não ter pretensões de trabalhar, mas viver de mendicância ou de auxílios governamentais ou de órgãos não governamentais, viver de forma violenta, não ajudando na construção de um país melhor, ou ainda deixando seus filhos entregues à própria sorte ou às custas de órgãos de proteção à criança, vivendo de maneira indigna, contrariando as conveniências. ${ }^{2}$

\footnotetext{
${ }^{1}$ Como se trata de um texto oral, não pudemos considerar a presença ou ausência da vírgula que poderia definir se a oração encaixada é restritiva ou explicativa.

${ }^{2}$ Interpretação que pode ser abonada em declarações feitas em comentários à matéria.
} 
Ainda, em continuidade à notícia, Dilma também teria dito na mesma ocasião: "Temos nossas dificuldades, mas isso não significa que no nosso país não caibam sempre mais pessoas." (ROUSEFF,2015 a)

Observamos a construção de uma oração adversativa: afirma-se " $x$ ", acrescenta-se a conjunção, "mas" e em seguida afirma-se "y", que nega a primeira proposição "x". Ao dizer “Temos nossas dificuldades, mas isso não significa que no nosso país não caibam sempre mais pessoas.", pode-se produzir uma leitura de ressalva, conforme vemos nas paráfrases:

Temos nossas dificuldades, mas isso não significa que no nosso país não caibam sempre mais pessoas.

\section{(ROUSSEFF,2015 a)}

Paráfrases:

Sempre cabem mais pessoas em nosso país, mas temos nossas dificuldades.

Em nosso país temos nossas dificuldades, mas receberemos aqueles que queiram vir.

$>$ Venham, mas saibam que temos nossas dificuldades.

Há ainda uma outra leitura possível do mesmo enunciado (1), aquela que considere uma função explicativa do 'que'. A primeira oração anuncia a condição do Brasil, país continental, (Somos um país continental), o que habilitaria a oferecer acolhida aos refugiados. Na sequência, vemos a inserção da conjunção " $e$ ”, que justifica e explica o porquê da primeira afirmação, ou seja, por sermos um país de dimensões continentais, podemos oferecer aos refugiados condições de trabalhar, viver em paz, ajudar na construção do país, criar seus filhos, e viver com dignidade. $O$ fato de estarmos de braços abertos deve-se, então, a nossa peculiaridade de país continental.

Na segunda inserção temos: Temos nossas dificuldades, mas isso não significa que no nosso país não caibam sempre mais pessoas. Observamos que o "mas", faz a mesma função do "e" na oração antecedente. Afirma-se "temos nossas dificuldades", apresentando novamente uma condição do Brasil, e na sequência, a conjunção "mas" explica que "isso não significa que no nosso país não caibam sempre mais pessoas".

É possível, a partir da reformulação do enunciado, chegar às seguintes paráfrases: 
Somos um país continental e todos os refugiados que quiserem vir trabalhar, viver em paz, ajudar a construir o país, criar seus filhos, viver com dignidade, nós estamos de braços abertos

Paráfrases:

Nós estamos de braços abertos a todos os refugiados que quiserem vir trabalhar, viver em paz, ajudar a construir o país, criar seus filhos, viver com dignidade, já que, somos um país continental.

Nós estamos de braços abertos a todos os refugiados que quiserem vir trabalhar, viver em paz, ajudar a construir o país, criar seus filhos, viver com dignidade, pois, somos um país continental.

Temos nossas dificuldades, mas isso não significa que no nosso país não caibam sempre mais pessoas. Paráfrase

Sempre cabem mais pessoas em nosso país, mesmo que tenhamos nossas dificuldades.

Vimos então duas análises linguísticas possíveis. Parece-nos frágil justificar uma ou outra leitura pelo contexto, ambas emergiram por ocasião da Assembleia Geral das Nações Unidas. Trata-se antes de apoiar-se em uma leitura discursiva que venha a abonar uma ou outra análise. Nesta direção a noção de série, de regularidade poderá nos auxiliar. A segunda análise oferece-se mais consistente porque encontramos nos demais enunciados (2 e 3 ) um domínio associado ao enunciado 1, além disso os três enunciados inscrevem-se no interior de um mesmo enunciado de referência e valendo-se de uma materialidade repetível:

Enunciado 1: (...) nós estamos de braços abertos

Enunciado 2: (...) Estamos abertos, de braços abertos para receber refugiados.

Enunciado 3: (...) o Brasil tem os braços abertos para acolher refugiados.

Cientes das redes que atravessam as formações discursivas, constatamos que nos três enunciados, como presidenta, Dilma enuncia em nome do "governo brasileiro", o que pressupõe que não apenas ela, como presidenta, está oferecendo acolhida, mas todo o corpo que governa o país. Suas declarações alinham-se em uma série discursiva produzindo uma rede cuja função enunciativa pode ser ocupada pela presidência, pelo partido, pelo Brasil, por todos os brasileiros: Queremos oferecer-lhe essa esperança (enunciado 3).

As políticas públicas ativadas durante o governo da Presidenta Dilma Rousseff, somadas a seu discurso pró imigração/pró refugiados, são coerentes com o 
posicionamento discursivo do governo que representa. Presidenta de um governo que discursivamente defende uma política inclusiva e de respeito às diferenças, autoriza uma leitura do enunciado (1) e não outra, uma vez que exclui pela lei da raridade outros sentidos: "essa raridade dos enunciados, a forma lacunar e retalhada do campo enunciativo, o fato de que poucas coisas, em suma, podem ser ditas, explicam que os enunciados não sejam, como o ar que respiramos, uma transparência infinita" (FOUCAULT, 2004, p. 136). Além do efeito de raridade, as noções de exterioridade e de acúmulo também sustentam a análise. A noção de exterioridade inscreve-se no conjunto das coisas ditas com as regularidades e transformações que podem ser observadas, indicando que esse que fala, ao enunciar, ocupa a função enunciativa de autor e como tal o que ele diz não é dito de qualquer lugar, mas no jogo de uma exterioridade. A noção de acúmulo na análise de discursos efetivamente enunciados reporta às marcas da instância de enunciação e reativam outros enunciados revelando, na densidade do acúmulo, a positividade de um discurso: "analisar uma formação discursiva é, pois tratar um conjunto de performances verbais no nível dos enunciados e da forma de positividade que as caracteriza" (FOUCAULT, 2004, p.142).

Os enunciados selecionados, especialmente o (2) e o (3), reafirmam ainda a posição de indignação do governo frente às mazelas que envolvem os migrantes e os refugiados. E essa indignação será o sentimento desencadeador de políticas públicas de atendimento a esses grupos.

enunciado 2: A profunda indignação provocada pela foto de um menino sírio morto nas praias da Turquia e pela notícia sobre as 71 pessoas asfixiadas em um caminhão na Áustria deve se transformar em ações inequívocas de solidariedade prática. Em um mundo onde circulam, livremente, mercadorias, capitais, informações e ideias, é absurdo impedir o livre trânsito de pessoas.

enunciado 3: Quando grandes crises se abateram sobre a Europa e sobre o Oriente, as portas do Brasil estiveram abertas para todos. Temos consciência da importância dessas contribuições para nossa formação histórica e cultural. Nós nos orgulhamos de ser um povo formado pela diversidade. É por isso que a tolerância e o respeito pelas diferenças são marcas da nossa identidade.

\subsection{Enunciados em análise: Jair Bolsonaro}

Em 24 de setembro de 2019, foi a vez de Jair Messias Bolsonaro discursar na $74^{\circ}$ Assembleia das Nações Unidas, já na condição de presidente da república. As declarações do $38^{\circ}$ presidente do Brasil se concentraram nas críticas ao governo petista 
que, segundo ele, quase teria levado o Brasil a um regime socialista. Ele também se defendeu das acusações que recebeu com relação à Amazônia, quando foi tomado por complacente, tolerante com as queimadas que devastaram parte da floresta em agosto de 2019. Além do clima, Bolsonaro também abordou questões sobre democracia e direitos humanos, em um pronunciamento permeado por enunciados de teor religioso. O site Agência Brasil ${ }^{3}$ transcreveu o discurso, do qual recortamos os seguintes excertos relacionados às questões migratórias:

\begin{abstract}
Enunciado 4
Em 2013, um acordo entre o governo petista e a ditadura cubana trouxe ao Brasil 10 mil médicos sem nenhuma comprovação profissional. Foram impedidos de trazer cônjuges e filhos, tiveram $75 \%$ de seus salários confiscados pelo regime e foram impedidos de usufruir de direitos fundamentais, como o de ir e vir. (...) A história nos mostra que, já nos anos 60 , agentes cubanos foram enviados a diversos países para colaborar com a implementação de ditaduras (BOLSONARO, na 74 ${ }^{\mathrm{a}}$ Assembleia da ONU, 2019)
\end{abstract}

Enunciado 5

Hoje o Brasil está mais seguro e ainda mais hospitaleiro. Acabamos de estender a isenção de vistos para países como Estados Unidos, Japão, Austrália e Canadá, e estamos estudando adotar medidas similares para China e Índia, dentre outros (BOLSONARO, na 74ª Assembleia da ONU, 2019)

\title{
Enunciado 6
}

Como os senhores podem ver, o Brasil é um país aberto ao mundo, em busca de parcerias com todos os que tenham interesse de trabalhar pela prosperidade, pela paz e pela liberdade (BOLSONARO, na $74^{\mathrm{a}}$ Assembleia da ONU, 2019).

Em continuidade às análises, avaliamos que os enunciados 4, 5 e 6, extraídos do pronunciamento do Bolsonaro na Assembleia Geral das Nações Unidas, expõem um discurso de posicionamento do governo não especialmente em relação aos povos em seus movimentos migratórios, mas em relação aos interesses e parcerias com outros países "que tenham interesse de trabalhar pela prosperidade, pela paz e pela liberdade" (enunciado 4).

As parcerias são definidas por supostos posicionamentos políticos que justificam avaliações sobre o povo de determinada nação. Fazendo uma associação do 'governo petista' com a 'ditadura cubana', em seu pronunciamento, o presidente desqualifica os

3 Disponível em: <http://agenciabrasil.ebc.com.br/politica/noticia/2019-09/presidente-jair-bolsonarodiscursa-na-assembleia-geral-da-onu >. Acesso em 14 de dezembro de 2019. 
cidadãos cubanos, atribuindo-lhes o papel de agentes cubanos". Há neste enunciado uma articulação arquivo-memória que indica como a lei de existência dos enunciados, com suas condições de emergência, responde aos modos de produção e transformação dos enunciados. $\mathrm{O}$ mesmo cidadão cubano que anteriormente migrou ao Brasil como um profissional da saúde passa a ser identificado como um 'agente da ditadura comunista'. Foucault (2010) apresenta como os enunciados são definidos por limites e formas (i) de dizibilidade (nas quais se estabelece sobre o que é possível falar em dado domínio discursivo), (ii) de conservação (selecionando quais enunciados são destinados a passar sem deixar vestígios e quais se cristalizam em nossa memória seja pela recitação, pelo ensino ou pela pedagogia), (iii) de memória (expondo como a inscrição dos discursos nas formações discursivas os tornam validados ou não, (iv) de reativação (buscando compreender quais discursos são reativados e porquê) e (v) de apropriação (que expõe a luta pelo domínio dos discursos).

O enunciado 4 está inscrito em um domínio de discursos de recitação da ditadura civil-militar no Brasil como um regime não ditatorial (buscando a reativação e a apropriação do discurso de defesa da presença dos generais na presidência como um regime de apoio e benevolência à nação) e os migrantes - profissionais médicos - são desqualificados por sua origem.

$\mathrm{Na}$ sequência do pronunciamento, a referência a um discurso de um Brasil de povo hospitaleiro remonta à carta de Ribeiro Couto $^{4}$ e reativa essa objetivação (FOUCAULT, 1995) do povo brasileiro como um povo cordial Diferentemente de Couto, que relaciona ao homem cordial características relacionadas à hospitalidade dos habitantes do Brasil, reativa-se ainda os estudos de Buarque de Holanda ${ }^{5}$, os quais retratam o 'homem cordial' de maneira etimológica, associando a cordialidade ao que provém da esfera do íntimo, do privado. Esse sentimento colaboraria para a tendência de fazer da esfera pública uma extensão da esfera privada, o que explicaria a propensão a entendimentos de leis, em prol de interesses próprios, justificando o hábito de beneficiar os 'nossos' em cargos, posições ou circunstâncias em que a razão, as leis e o mérito deveriam se sobrepor (CORSI, 2019).

Neste enunciado (5), podemos perceber a preferência de Bolsonaro por certas nacionalidades, as quais ele julga superiores às demais. A deferência de isenção de

\footnotetext{
${ }^{4}$ O "Homem Cordial", como expressão, nasceu de uma carta escrita pelo poeta, Rui Esteves Ribeiro de Almeida Couto, na década de 1930 ao então embaixador do México no Brasil, Alfonso Reyes.

${ }^{5}$ Sérgio Buarque de Holanda, no livro Raízes do Brasil, de 1936.
} 
vistos é feita pelo presidente para alguns. Não se trata de uma política pública, tampouco migratória. O funcionamento retoma aquele do benefício aos supostamente 'nossos'. Em 23 de julho de 2019, Bolsonaro demonstrou novamente que sua 'antipatia" por certos grupos de estrangeiros é mais de cunho político que necessariamente cultural ou humanitário.

De modo a expormos essa posição de deferência no acúmulo de enunciados, recuperamos a fala do presidente numa palestra na sede da Hebraica, no Rio de Janeiro, em 3 de abril de 2017, quando era deputado federal, e esboçou admiração pelos japoneses: "Alguém já viu algum japonês pedindo esmola? É uma raça que tem vergonha na cara!" (VEJA, 2017) ${ }^{6}$. Ou ainda em 23 de julho de 2019, quando Bolsonaro demonstrou novamente sua "antipatia" por certos grupos de estrangeiros: "Governo Bolsonaro retira status de refugiado de três paraguaios: 'O Brasil não mais será refúgio de canalhas travestidos de presos políticos"” (O GLOBO $)^{7}$

$\mathrm{Na}$ análise do enunciado 6, podemos retornar à análise de possíveis paráfrases que no cotejamento indicam que a semelhança de sentidos da enunciação dos dois presidentes desfaz-se ao se considerar o plano discursivo.

"Somos um país continental e todos os refugiados que quiserem vir trabalhar, viver em paz, ajudar a construir o país, criar seus filhos, viver com dignidade, nós estamos de braços abertos"(Dilma Rousseff) Paráfrases:

O Brasil é um país continental e estamos de braços abertos aos refugiados desde que venham para trabalhar, viver em paz, ajudar a construir o país, criar seus filhos e viver com dignidade.

Nós estamos de braços abertos a todos os refugiados que quiserem vir trabalhar, viver em paz, ajudar a construir o país, criar seus filhos, viver com dignidade, já que, somos um país continental.

Como os senhores podem ver, o Brasil é um país aberto ao mundo, em busca de parcerias com todos os que tenham interesse de trabalhar pela prosperidade, pela paz e pela liberdade. (Jair Bolsonaro) Paráfrases:

Como os senhores podem ver, o Brasil é um país aberto ao mundo, em busca de parcerias desde que tenham interesse de trabalhar pela prosperidade, pela paz e pela liberdade.

[Desde que] Para parcerias de trabalho (pela prosperidade, pela paz e pela liberdade), como os senhores podem ver, o Brasil é um país aberto ao mundo.

\footnotetext{
${ }^{6}$ Disponível em: < https://veja.abril.com.br/brasil/bolsonaro-e-acusado-de-racismo-por-frase-em-palestrana-hebraica/>. Acesso em 26 de dezembro de 2019.

${ }^{7}$ Disponível em: $<$ https://oglobo.globo.com/mundo/governo-bolsonaro-retira-status-de-refugiado-de-tresparaguaios-23826364>. Acesso em: 15 de dezembro de 2019. Acesso em: 15 de dezembro de 2019.
} 


\section{A positividade do discurso}

Neste exercício procuramos mostrar como a análise dos acúmulos, a descrição das relações de exterioridade, e a análise da raridade mostram a unidade de um discurso para além do personalismo político. Pudemos ver que os enunciados se organizam em uma mesma formação discursiva e revelam a positividade de um discurso. Esse campo da positividade pode ser desenvolvido por "identidades formais, continuidades temáticas, translações de conceitos, jogos polêmicos" (FOUCAULT, 2004, p.144)

Vimos que as identidades formais dos enunciados 1 e 6 poderiam, por uma análise superficial, atrair para um mesmo campo os discursos dos dois presidentes sobre política migratória. As continuidades temáticas, entretanto, rapidamente os separam. Em enunciações posteriores àquela da ONU, Jair Bolsonaro reafirma a suposta soberania da nação em primazia ao interesse humanitário.

Enunciado 8. O Brasil é soberano para decidir se aceita ou não migrantes. Quem porventura vier para cá deverá estar sujeito às nossas leis, regras e costumes, bem como deverá cantar nosso hino e respeitar nossa cultura. Não é qualquer um que entra em nossa casa, nem será qualquer um que entrará no Brasil via pacto adotado por terceiros. NÃO AO PACTO MIGRATÓRIO. (twitter@jairbolsonaro, 2019) $^{8}$

Observamos no enunciado de Bolsonaro a ruptura que pretende estabelecer entre seu governo e os governos anteriores, em especial governos petistas. Notamos também a afinidade com a política migratória de Donald Trump, que também não aderiu ao pacto. O presidente Bolsonaro se desligou do Pacto Migratório ${ }^{9}$, assinado pelo governo Temer, por meio de um telegrama emitido em 8 de janeiro de 2019. Segundo o trecho disponibilizado pelo Jornal BBC, coube ao Ministério das Relações Exteriores, por meio dos diplomatas brasileiros, tornar esse desligamento conhecido a todos os interlocutores relevantes, sobretudo ao Secretário-Geral das Nações Unidas e ao Diretor Geral da Organização Internacional de Migração, por meio de nota, a dissociação do Brasil do Pacto Global para Migração Segura, Ordenada e Regular. (BBC, 2019) ${ }^{10}$.

\footnotetext{
${ }^{8}$ Disponível em: <https://twitter.com/jairbolsonaro/status/1082924268361519104/photo/1 >. Acesso em 16 de dezembro de 2019.

${ }^{9}$ O Pacto Global para Migração, é um acordo firmado entre 164 países que visa gerenciar a migração internacional identificando as motivações para os deslocamentos e minimizando-as. Entre outros objetivos busca assegurar aos migrantes, condições de deslocamento, realocação e possível regresso aos países de origem de forma digna, reconhecendo e garantindo seus direitos. Nas palavras do secretáriogeral da ONU, António Guterres, o pacto "reafirma os princípios fundamentais de nossa comunidade global, incluindo soberania nacional e direitos humanos universais, enquanto aponta o caminho em direção à ação humana e sensata para beneficiar países de origem, de trânsito e de destino, assim como os próprios migrantes". (NAÇÕES UNIDAS, 2018).

10 Disponível em: < https://www.bbc.com/portuguese/brasil-46802258>. Acesso em 07 de janeiro de 2020.
} 
Enunciado 9. "Jamais recusaremos ajuda aos que precisam, mas a imigração não pode ser indiscriminada. É necessário [ter] critérios, buscando a melhor solução de acordo com a realidade de cada país. Se controlamos quem deixamos entrar em nossas casas, por que faríamos diferente com o nosso Brasil'?

A defesa da soberania nacional foi uma das bandeiras de nossa campanha e será uma prioridade do nosso governo. Os brasileiros e os imigrantes que aqui vivem estarão mais seguros com as regras que definiremos por conta própria, sem pressão do exterior. (ESTADO DE MINAS, 2019) ${ }^{11}$.

O enunciado 9 ilustra fielmente dois aspectos fundamentais da política de imigração do governo Bolsonaro. Primeiro, sua acolhida condicional, restritiva; e depois a visão do estrangeiro como ameaça, maquiada pelo pretexto da manutenção da soberania. A hospitalidade de Bolsonaro, bem como sua tolerância a imigrantes, está condicionada as suas inclinações pessoais e suas convicções políticas (Se controlamos quem deixamos entrar em nossas casas, por que faríamos diferente com o nosso Brasil?). Suas decisões se pautam na crença ou na dissimulação de uma crença que coloca o imigrante como potencial criminoso.

Quando Bolsonaro afirma "Jamais recusaremos ajuda aos que precisam, mas a imigração não pode ser indiscriminada", fica pressuposto que ele nega que haja critérios para a imigração, ignorando todas as leis que discorrem sobre esse tema no Brasil. O uso do mas, conjunção adversativa, é utilizado para negar a primeira proposição parcialmente ou totalmente, e, nesse caso, serve para mostrar que recusar ajuda aos que precisam é uma possibilidade concreta para o presidente, e que está condicionada a seus próprios critérios.

\section{Considerações finais}

Em repetidas vezes somos chamados a responder sobre a produtividade das reflexões de Michel Foucault para a os estudos discursivos inscritos no âmbito das teorias e análises linguísticas. Este artigo pretendeu de fato expor um exercício de análise que, de forma didática, pudesse problematizar o alcance e a articulação de diferentes formas de análise. "A Arqueologia do Saber" permite que façamos esse recorte, entretanto, ressaltamos que a proposição da obra não se reduz a essa tarefa, aliás

\footnotetext{
${ }^{11}$ Disponível em: https://www.em.com.br/app/noticia/politica/2019/01/09/interna_politica,1019996/presidente-diz-quebrasil-jamais-se-recusara-a-ajudar-imigrantes.shtml>. Acesso em 12 de janeiro de 2020.
} 
ela é bem mais ampla, oferecendo-nos sobretudo o questionamento dos saberes, a dimensão dos discursos, a problematização dos arquivos. Alguns desses temas, pudemos explorar em artigos nos quais analisamos a centralidade da noção de arquivo para as análises (SARGENTINI, 2015), as contribuições de Michel Foucault aos domínios da linguagem (SARGENTINI e NAVARRO, 2004) e as discussões inaugurais sobre o discurso (SARGENTINI, 2019).

Aos leitores gostaríamos de ponderar que o termo 'enunciado', presente muitas vezes neste artigo, pode ora ser lido como um enunciado linguístico no sentido de uma proposição ou de uma frase e ora ser evocado pela definição que lhe atribui Foucault, que dedica um capítulo no livro A Arqueologia do saber para desfazer possíveis equívocos. Nossa proposta de problematizar o alcance deste conceito no interior de diferentes perspectivas parece ter nos levado algumas vezes a essa possível leitura ambígua.

Os resultados desta análise, entretanto, não foram a nosso ver somente de caráter de um exercício didático. O cotejamento do discurso dos dois distintos governantes levou-nos a avaliar como as diferentes posições enunciativas conduzem a formações discursivas distintas. Pautados em nossa análise, observamos que a distinção marca-se pela posição enunciativa assumida no enunciado 1 nós estamos de braços abertos, no qual se pode subsumir no 'nós' a soma de eu governante + Brasil + povo brasileiro, enquanto no enunciado 6 há um distanciamento daquele que enuncia e quem está de braços abertos é o Brasil administrativo - aquele que busca parcerias que lhe sejam convenientes $O$ Brasil é um país aberto ao mundo para parcerias de trabalho.

O domínio de memória, que vem a inscrever os discursos nas formações discursivas, tornando-os validados ou não, é que nos assegura ainda mais uma vez uma leitura de divergência das enunciações dos dois presidentes. Além disso, as análises revelam nos enunciados da ex-presidenta Dilma o discurso de acolhimento da diversidade e a necessidade de políticas públicas de atendimento aos migrantes e refugiados motivadas pela indignação com as dificuldades que atingem a humanidade.

$\mathrm{Na}$ análise pautada no acúmulo das enunciações do governo Jair Bolsonaro não é aos povos (migrantes ou refugiados) que ele se refere. O Brasil, acima de tudo superpõe-se aos povos. O projeto que se faz não é o de políticas públicas para acolhimento, mas o desejo de um projeto de parcerias promissoras com aquelas nações escolhidos. A atitude do governo é de reparação do ressentimento, uma necessidade de reparação que faz expulsar cubanos e paraguaios dentre outros. 
Com isso, vemos duas políticas migratórias que se diferenciam sobretudo porque se fundam em formações discursivas e sentimentos distintos: a indignação e o ressentimento. $\mathrm{O}$ primeiro é o motor para políticas públicas que atendam à coletividade, o segundo reduz-se ao desejo particular, à reparação daqueles que se sentiram feridos. Distinguir esses dois sentimentos é definidor para assentar-se em um ou outro lado da história.

Agradecimento: À Profa. Dra. Luzmara Curcino que, com suas profícuas discussões na arguição de defesa da dissertação de mestrado intitulada "Na Fronteira da Intolerância ecos de povos em deslocamento", motivou-nos a elaborar este artigo.

\section{REFERÊNCIAS}

CAVALCANTI, L; OLIVEIRA, T.; MACEDO, M., Imigração e refúgio no Brasil. Relatório anual 2019. Série Migrações. Observatório das Migrações Internacionais; Ministério da Justiça e Segurança Pública/ Conselho Nacional de Imigração e Coordenação Geral de Imigração Laboral. Brasília, DF: OBMigra, 2019.

CORSI, Joice Na fronteira da intolerância: ecos de povos em deslocamento. Dissertação de Mestrado apresentada ao Programa de Pós-Graduação em Linguística da Universidade Federal de São Carlos (UFSCar), São Carlos, 2020.

ROUSSEFF, Dilma Todo refugiado que queira trabalhar é bem-vindo no Brasil, diz Dilma. G1, 2015a. Excerto da entrevista dada pela então presidenta, Dilma Rousseff a jornalistas por ocasião da $70^{\text {a }}$ Assembleia Geral das Nações Unidas (ONU). Disponível em: <http://g1.globo.com/mundo/noticia/2015/09/todo-refugiado-que-queira-trabalhare-bem-vindo-no-brasil-diz-dilma.html>. Acesso em 14 dez. de 2019.

ROUSSEFF, Dilma Discurso da Presidenta da República, Dilma Rousseff, por ocasião da Abertura da Septuagésima Assembleia Geral das Nações Unidas - Nova York, 28 de setembro de 2015. ITAMARATY, 2015b. Disponível em: < http://www.itamaraty.gov.br/pt-BR/discursos-artigos-e-entrevistas-categoria/presidenteda-republica-federativa-do-brasil-discursos/11918-discurso-da-presidenta-da-republicadilma-roussef-por-ocasiao-da-abertura-da-septuagesima-assembleia-geral-das-nacoesunidas-nova-york-28-de-setembro-de-2015>. Acesso em 14 dez. 2019.

ROUSSEFF, Dilma Os refugiados e a esperança. FOLHA UOL, 2015c.

Disponível em: < https://m.folha.uol.com.br/opiniao/2015/09/1679691-os-refugiados-ea-esperanca.shtml >. Acesso em 14 dez. 2019.

FOUCAULT, Michel O sujeito e o poder. In: RABINOW, Paul e DRYFUS, Hubert Michel Foucault. Uma trajetória filosófica. Para além de estruturalismo e da Hermenêutica. Rio de Janeiro: Forense Universitária, 1995.

FOUCAULT, Michel A ordem do discurso. São Paulo: Loyola, 1996 
FOUCAULT, Michel A arqueologia do Saber. Trad. De Felipe Baeta Neves. $7^{\mathrm{a}}$ edição. Rio de Janeiro: Forense Universitária, 2004.

FOUCAULT, M. Resposta a uma questão. In: Ditos e escritos VI. Rio de Janeiro:

Forense Universitária, 2010. pp.1-24.

HOLANDA, Sérgio Buarque de. O homem cordial. In: Raízes do Brasil: $26^{\circ}$ edição. São Paulo: Companhia das Letras, 1995.

JAIR BOLSONARO Veja a íntegra do discurso de Bolsonaro na Assembleia Geral da ONU. AGENCIA BRASIL, 2019. Excerto do pronunciamento do presidente, Jair Bolsonaro por ocasião da $74^{a}$ Assembleia Geral das Nações Unidas (ONU).

Disponível em: < https://agenciabrasil.ebc.com.br/politica/noticia/2019-09/presidentejair-bolsonaro-discursa-na-assembleia-geral-da-onu >. Acesso em 14 dez. 2019.

REVEL, Judith Foucault, une pensée du discontinu. Paris: Mille et une nuits, 2010.

SARGENTINI, Vanice $O$ arquivo e a circulação de sentidos. Revista Conexão Letras, Porto Alegre, RS, v. 9, n. 11, abr. 2015. ISSN 2594-8962. Disponível em: <https://seer.ufrgs.br/conexaoletras/article/view/55139>. Acesso em: 06 jul. 2020. doi:https://doi.org/10.22456/2594-8962.55139.

SARGENTINI, Vanice Há em Foucault um gesto inaugural nos estudos do discurso? Revista Heterotópica, v. 1, n. 1, p. 34-47, 26 jun. 2019.

SARGENTINI, Vanice e NAVARRO. P. (Org.) M. Foucault e os domínios da linguagem: discurso, poder, subjetividade. São Carlos: Claraluz, 2004. 